\title{
Succession of microbial functional communities in response to a pilot- scale ethanol-blended fuel release throughout the plume life cycle
}

\author{
Jie Ma ${ }^{\mathrm{a}, \mathrm{b}}$, Ye Deng ${ }^{\mathrm{c}, \mathrm{d}}$, Tong Yuan ${ }^{\mathrm{d}}$, Jizhong Zhou ${ }^{\mathrm{d}, \mathrm{e}, \mathrm{f}}$, Pedro J.J. Alvarez ${ }^{\mathrm{b}, *}$ \\ a State Key Laboratory of Heavy Oil Processing, Beijing Key Lab of Oil \& Gas Pollution Control, China University of Petroleum-Beijing, Beijing 102249, China \\ b Department of Civil and Environmental Engineering, Rice University, Houston, TX 77005, USA \\ ${ }^{\mathrm{c}}$ Research Center for Eco-Environmental Science, Chinese Academy of Sciences, Beijing 100085, China \\ d Institute for Environmental Genomics, and Department of Microbiology and Plant Biology, University of Oklahoma, Norman, OK 73019, USA \\ e State Key Joint Laboratory of Environment Simulation and Pollution Control, School of Environment, Tsinghua University, Beijing 100084, China \\ ${ }^{\mathrm{f}}$ Earth Science Division, Lawrence Berkeley National Laboratory, Berkeley, CA 94270, USA
}

\section{A R T I C L E I N F O}

\section{Article history:}

Received 21 October 2014

Received in revised form

8 January 2015

Accepted 10 January 2015

Available online 17 January 2015

\section{Keywords:}

Fuel ethanol

Metagenomics

Biodegradation

Resilience

Groundwater

Remediation

\begin{abstract}
A B S T R A C T
GeoChip, a comprehensive gene microarray, was used to examine changes in microbial functional gene structure throughout the 4-year life cycle of a pilot-scale ethanol blend plume, including 2-year continuous released followed by plume disappearance after source removal. Canonical correlation analysis (CCA) and Mantel tests showed that dissolved $\mathrm{O}_{2}$ (which was depleted within 5 days of initiating the release and rebounded 194 days after source removal) was the most influential environmental factor on community structure. Initially, the abundance of anaerobic BTEX degradation genes increased significantly while that of aerobic BTEX degradation genes decreased. Gene abundance for N fixation, nitrification, $\mathrm{P}$ utilization, sulfate reduction and $\mathrm{S}$ oxidation also increased, potentially changing associated biogeochemical cycle dynamics. After plume disappearance, most genes returned to pre-release abundance levels, but the final functional structure significantly differed from pre-release conditions. Overall, observed successions of functional structure reflected adaptive responses that were conducive to biodegradation of ethanol-blend releases.
\end{abstract}

() 2015 Published by Elsevier Ltd.

\section{Introduction}

Microorganisms play vital roles in key biogeochemical cycles in virtually all of our planet's environments, thus comprising the backbone of most ecological systems (Zhou et al., 2014). Therefore, unraveling microbial responses to environmental perturbations is a central goal for environmental microbiologists (Allison and Martiny, 2008; Shade et al., 2012). As a typical environmental perturbation, fossil fuel releases pose a big threat to groundwater biosphere, which despite constituting the largest terrestrial freshwater biome, it remains amongst the least explored habitats on earth (Griebler et al., 2014). The growing use of ethanol as transportation biofuel is increasing the likelihood of encountering it in fuel releases, where it may hinder the natural attenuation of co-occurring contaminants such as benzene, toluene, ethylbenzene and xylenes (BTEX) (Corseuil et al., 1998; Ma et al., 2013b; Powers et al., 2001a, 2001b).

\footnotetext{
* Corresponding author.

E-mail address: alvarez@rice.edu (P.J.J. Alvarez).
}

Therefore, it is important to understand how ethanol-blended fuel releases influence the succession and functioning of indigenous microbial communities in impacted aquifers, and the associated microbial functional structure and bioremediation processes.

The impacts of ethanol-blended fuel releases on microbial phylogenetic structure have been investigated via 16S rRNA pyrosequencing (Ma et al., 2013a), denaturing gradient gel electrophoresis (DGGE) (Capiro et al., 2008; Elazhari-Ali et al., 2013) and automated ribosomal intergenic space analysis (ARISA) (Nelson et al., 2010). Although these $16 \mathrm{~S}$ rRNA-based studies provided useful taxonomic and phylogenetic information regarding resulting microbial population shifts, little is known about the associated changes in functional structure and metabolic potential.

Several individual functional genes such as mcrA (methanogenesis), fhs (acetogenesis), aps (sulfate reducing), nirK and nirS (nitrate reducing), PHE and TOD (BTEX aerobic degradation), and bssA (BTEX anaerobic degradation) have been previously investigated in aquifers impacted by ethanol blends (Beller et al., 2008; Capiro et al., 2008; da Silva and Corseuil, 2012; Feris et al., 2008; Ma et al., 2013a). However, these studies provided only partial 
information regarding a limited number of functional genes. A more comprehensive characterization of microbial functional structure is needed. As a high-throughput functional gene microarray, GeoChip is well suited for this purpose and it has been successfully applied to characterize microbial functional diversity in a variety of environments (Chan et al., 2013; Hazen et al., 2010; Wang et al., 2009; Zhou et al., 2014, 2012).

Another knowledge gap relates to how the microbial community responds after the contaminant source is removed and the plume is attenuated or remediated, since previous research has mainly focused on microbial responses before (baseline) and after the contamination occurs. Improved understanding of the microbial response after source removal may help optimize site management strategies for biofuel releases.

In this study, GeoChip 4.6 was used to characterize the dynamics of microbial functional structure in response to 1) a pilot-scale, continuous (two-year) ethanol blend release, and 2) its subsequent shut-off and natural attenuation over two additional years. Therefore, the succession of the microbial community was considered throughout the life cycle of the plume. The pilot-scale experiments were unique in that they are of sufficient scale such that more realistic three-dimensional contaminant plumes can be established, but at a small enough scale to provide sufficiently controlled experimental conditions. Chemical concentrations (e.g., ethanol, benzene, toluene, methane, acetate, butyrate, and butanol) and environmental variables (e.g., temperature, $\mathrm{pH}$, redox potential, and dissolved oxygen) were monitored to enhance the interpretation of GeoChip data.

\section{Materials and methods}

\subsection{Pilot-scale model aquifer system}

An $8-\mathrm{m}^{3}(3.7 \mathrm{~m} \times 1.8 \mathrm{~m} \times 1.2 \mathrm{~m})$ pilot-scale continuous-flow tank packed with fine grain southeast Texas sand (Circle Sand; Houston, Texas) was used in this study (Fig. S1 in the supporting information). Tap water was added from the "inlet" (Fig. S1) at $170 \mathrm{~L} /$ day (average seepage velocity of $2.5 \mathrm{ft} / \mathrm{day}$ ) to obtain a water table elevation of about $70 \mathrm{~cm}$ from the bottom of the tank. The groundwater retention time in this model tank was around 4 days. The total aquifer thickness was $115 \mathrm{~cm}$ and the depth of the water table was $45 \mathrm{~cm}$ below ground surface. The ethanol blend solution was a water solution containing $10 \%(\mathrm{v} / \mathrm{v})$ ethanol, $50 \mathrm{mg} / \mathrm{L}$ benzene, $50 \mathrm{mg} / \mathrm{L}$ toluene and $24000 \mathrm{mg} / \mathrm{L}$ of sodium bromide ( $\mathrm{NaBr}$ ). The blend solution was continuously injected into the tank from the ethanol blend injection port $(22.5 \mathrm{~cm}$ below the water table $)$ at a rate of $0.4 \mathrm{~L}$ /day for 10 months. $\mathrm{NaBr}$ was added as a conservative tracer, and to maintain a solution density to reach neutral buoyancy with the flowing groundwater. The added $\mathrm{NaBr}$ was diluted by the tank flow to less than $2000 \mathrm{mg} / \mathrm{L}$ (measured at groundwater sampling well, see Fig. 1), which was within the typical tolerance range of soil bacteria (Atlas and Bartha, 1997). The groundwater sampling well was at the same depth as the ethanol blend injection port (22.5 $\mathrm{cm}$ below the water table). Details on the tank construction and packing methods can be found in (Ma et al., 2011) and (Ma et al., 2012).

\subsection{Release stages and plume life cycle}

This pilot-scale release experiment lasts for 4 years, which could be divided into 4 experimental stages (Fig. 1). General information for each stage can be found in Table 1 . Stage 1 was the pre-release baseline. Stage 2 began with the continuous ethanol blend release (10\% ethanol $+50 \mathrm{mg} / \mathrm{L}$ benzene $+50 \mathrm{mg} / \mathrm{L}$ toluene) and lasts for 2 years. Stage 3 followed the removal of ethanol from the continuous release, resulting in continuous exposure to $50 \mathrm{mg} / \mathrm{L}$ benzene and $50 \mathrm{mg} / \mathrm{L}$ toluene continues for 8 months. This mimicked the earlier removal of ethanol than BTEX at contaminated sites (Corseuil et al., 2011; Freitas and Barker, 2013; Freitas et al., 2011a, 2011b; Mackay et al., 2006; Spalding et al., 2011). Stage 4 was the return to initial conditions (benzene and toluene removed from the tank influent), when clean water flowed through the aquifer material for 4 months. At the end of each experimental stage, sand samples were collected for GeoChip and soil property analysis, and groundwater samples were collected for chemical and geochemical analysis. The sampling date can be found in Table 1.

\subsection{Analysis of groundwater pollutants and geochemical parameters}

For chemical analysis, four replicate groundwater samples were collected from the groundwater sampling well using $50 \mathrm{~mL}$ syringes at the end of each experimental stage. Ethanol, methane, acetate, propionate, butyrate and butanol were measured by GCFID (Hewlett Packard, Palo Alto, CA, USA). Ethanol, acetate, propionate, butyrate, and butanol were measured by liquid injections while methane was measured by headspace injections. The detection limits (aqueous concentration) were $1 \mathrm{mg} / \mathrm{L}$ for ethanol, acetate, and propionate, $2 \mathrm{mg} / \mathrm{L}$ for butyrate and butanol, and $0.1 \mathrm{mg} / \mathrm{L}$ for methane. Benzene and toluene were pre-concentrated by Purge and Trap System (Tekmar, Vernon, BC, Canada) and measured by GC-MS (Agilent, Santa Clara, CA, USA) with a detection limit of $10 \mu \mathrm{g} / \mathrm{L}$ (aqueous concentration). Details on chemical measurement methods can be found in Ma et al., 2011.

Groundwater geochemical parameters at Stage 1 and $2(\mathrm{pH}$, dissolved $\mathrm{O}_{2}$, temperature, and redox potential) were monitored by a YSI 600XLM groundwater quality probe (YSI, Yellow Springs, Ohio, USA) which was installed $15 \mathrm{~cm}$ upstream from the groundwater sampling well (Fig. 1). After Stage 2, this probe broke, thus no redox data was available since then. For Stage 3 and 4, the temperature was measured by a Pen-Style Thermometer (Taylor Precision Products, Oak Brook, IL, USA); dissolved $\mathrm{O}_{2}$ (DO) was measured by a Dissolved Oxygen AccuVac ${ }^{\circledR}$ Ampules kit (Hach, Loveland, CO, USA); pH was measured by a Pocket pH Tester (Davis Instruments, Vernon Hills, IL, USA). Groundwater geochemical data can be found in Table 1 .

\subsection{Sand sampling and analysis}

Sand samples were collected in 5 replicates from a depth of $5-30 \mathrm{~cm}$ below water table $(50-75 \mathrm{~cm}$ below the sand surface, Fig. S1) on the same day when groundwater samples were collected. Details on sand sampling method can be found in (Ma et al., 2013a). Dry sand samples were sent to the Soil, Water and Forage Testing Laboratory at Texas A\&M University for the measurement of soil $\mathrm{pH}$, total organic carbon content, conductivity, nitrate-nitrogen, $\mathrm{P}, \mathrm{K}, \mathrm{Ca}, \mathrm{Mg}, \mathrm{S}$, and $\mathrm{Na}$ (Table S1). Details on soil analytical methods can be found in the supporting information.

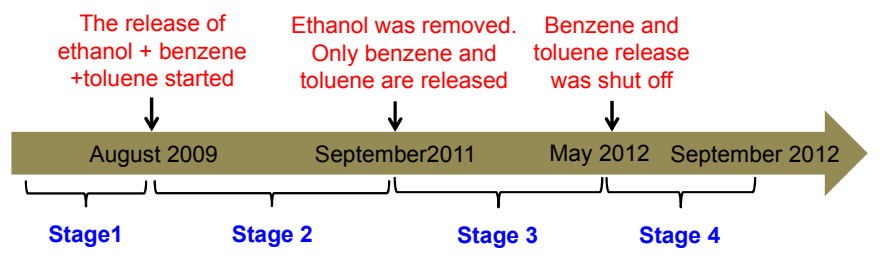

Fig. 1. Timeline of the pilot-scale release experiment. 
Table 1

General information for each experimental stage.

\begin{tabular}{|c|c|c|c|c|}
\hline Experimental stage & Stage 1 & Stage 2 & Stage 3 & Stage 4 \\
\hline Sampling date & $8 / 7 / 2009$ & $9 / 5 / 2011$ & $5 / 4 / 2012$ & $9 / 2 / 2012$ \\
\hline Action & Pre-release baseline & $\begin{array}{l}\text { Exposed to ethanol, benzene and } \\
\text { toluene mixture for } 2 \text { years }\end{array}$ & $\begin{array}{l}\text { Exposed to benzene and } \\
\text { toluene mixture for } 8 \text { months }\end{array}$ & $\begin{array}{l}\text { Exposed to clean water for } \\
4 \text { months after Stage } 3\end{array}$ \\
\hline \multicolumn{5}{|l|}{ Chemical concentration in the groundwater } \\
\hline Ethanol $(\mathrm{mg} / \mathrm{L})$ & 0.0 & 3269.5 & 0.0 & 0.0 \\
\hline Benzene $(\mu \mathrm{g} / \mathrm{L})$ & 0.0 & 83.1 & 1121.0 & 0.0 \\
\hline Toluene $(\mu \mathrm{g} / \mathrm{L})$ & 0.0 & 38.3 & 6.4 & 0.0 \\
\hline Methane (mg/L) & 0.0 & 28.5 & 0.0 & 0.0 \\
\hline Acetate $(\mathrm{mg} / \mathrm{L})$ & 0.0 & 116.0 & 0.0 & 0.0 \\
\hline Butyrate (mg/L) & 0.0 & 267.0 & 0.0 & 0.0 \\
\hline Butanol (mg/L) & 0.0 & 72.0 & 0.0 & 0.0 \\
\hline \multicolumn{5}{|l|}{ Geochemical footprints } \\
\hline $\mathrm{pH}$ & 7.2 & 4.7 & 7.8 & 7.6 \\
\hline Dissolved oxygen $(\mathrm{mg} / \mathrm{L})$ & $5.1 \pm 0.4$ & $0.0 \pm 0.0$ & $1.6 \pm 0.2$ & $2.1 \pm 0.3$ \\
\hline Temperature $\left({ }^{\circ} \mathrm{C}\right)$ & 29.1 & 28.5 & 26.3 & 27.9 \\
\hline Redox potential $(\mathrm{mV})$ & $108.3 \pm 6.1$ & $-402.3 \pm 7.6$ & NA & NA \\
\hline Prevailing electron accepting conditions & Aerobic & Methanogenic & Aerobic & Aerobic \\
\hline
\end{tabular}

\subsection{GeoChip hybridization and data processing}

GeoChip 4.6 contains $\sim 82000$ gene probes covering 142000 coding sequences from 410 gene families that were essential to the biogeochemical cycling of carbon, nitrogen, sulfur, and phosphorus, organic contaminant remediation, energy metabolism, antibiotic resistance, metal resistance/reduction, stress response, virulence, and bacterial phage genes (Tu et al., 2014). The coding sequences are retrieved from 173 archaeal, 4138 bacterial, 404 eukaryotic and 252 viral strains (Tu et al., 2014). In this study, 12 DNA samples (4 stages $\times 3$ replicates at each stage) were used for GeoChip analysis. DNA was extracted from $10 \mathrm{~g}$ sand (collected from the same location) using a modified PowerMax Soil DNA isolation kit (MOBIO, Carlsbad, CA, US) with several modifications (see supporting information) to increase DNA yield. For each sample, $800 \mathrm{ng}$ DNA was used for hybridization at $42{ }^{\circ} \mathrm{C}$ for $16 \mathrm{~h}$ on MUNI hybridization station in the presence of $40 \%$ formamide (BioMicro Systems, Salt Lake City, UT, USA). Details on DNA extraction, GeoChip hybridization, scanning and data processing can be found in the supporting information.

\subsection{Statistical analysis of GeoChip data}

Non-metric multi-dimensional scaling analysis (NMDS) based on Bray-Curtis matrix was used to determine overall changes in the functional structure. Non-parametric multivariate analysis of variance (adonis) was used to examine whether such changes in

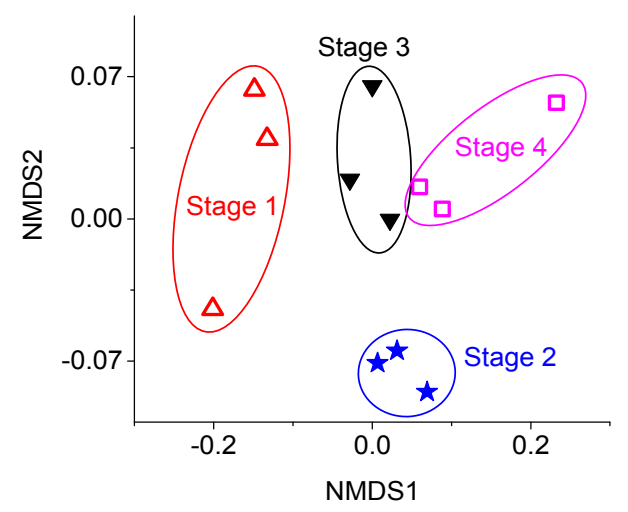

Fig. 2. Non-metric multi-dimensional scaling analysis of Bray-Curtis similarities for the overall functional gene structure. the functional structure are statistically significant. Canonical correspondence analysis (CCA) was performed to discern the relationship between functional gene structure and measured environmental variables using the software $\mathrm{R}$ (version 2.9.1). Mantel test was performed using the software $\mathrm{R}$ to determine whether the correlations between functional gene structure and measured environmental variables were statistically significant.

\section{Results and discussion}

\subsection{Geochemical footprint of the release at different experimental stages}

As the pre-release baseline, Stage 1 represented aerobic $(5.1 \mathrm{mg} / \mathrm{L}$ of DO) and oligotrophic (no pollutants) conditions. Stage 2 represented exposure to the ethanol-blend release for two years, and was characterized by highly reducing anaerobic conditions $(-402.3 \mathrm{mV}$ of redox potential) (Table 1 and Fig. S2). Fermentative activities resulted in a decrease in $\mathrm{pH}$ (to 4.7) during Stage 2. Stage 3 followed the removal of ethanol from the source (to mimic the earlier removal of ethanol than BTEX at contaminated sites); continuous release of benzene and toluene (at $50 \mathrm{mg} / \mathrm{L}$ each) continued for 8 months. The DO increased to $1.6 \mathrm{mg} / \mathrm{L}$ and $\mathrm{pH}$ rebounded to near-neutral levels during Stage 3. Stage 4 was the return to initial conditions (benzene and toluene removed from the tank influent) and the aquifer material was exposed to clean water for 4 months.

\subsection{Changes in functional structure in response to continuous release and subsequent shutdown}

The functional gene structure significantly changed in response to the continuous release of ethanol blend solution and the following shut-off of such release. Multi-dimensional scaling analysis (NMDS) showed that all 12 samples were well clustered by corresponding experimental stages. The average distance between replicates from the same stage was much smaller than that the average distance between samples from different stages, indicating that within-stage gene heterogeneity (among 3 replicates at the same stage) was much smaller than between-stage gene heterogeneity (among 4 stages) (Fig. 2). This was further corroborated by the number of overlapping gene shared by different samples (Table S2). Samples from the same experimental stage shared more overlapping genes than samples from other stages (Table S2). Adonis dissimilarity test (Permutational Multivariate Analysis of Variance) further confirmed that the pair-wise differences between 
Table 2

Dissimilarity test of adonis.

\begin{tabular}{lll}
\hline & $\mathrm{R}^{2}$ & $p$ value $^{\mathrm{a}}$ \\
\hline Stage 1 vs Stage 2 & 0.687 & $\mathbf{0 . 0 0 1}$ \\
Stage 1 vs Stage 3 & 0.645 & $\mathbf{0 . 0 0 1}$ \\
Stage 1 vs Stage 4 & 0.631 & $\mathbf{0 . 0 2 2}$ \\
Stage 2 vs Stage 3 & 0.491 & $\mathbf{0 . 0 4 2}$ \\
Stage 2 vs Stage 4 & 0.423 & $\mathbf{0 . 0 0 1}$ \\
Stage 3 vs Stage 4 & 0.435 & 0.096 \\
\hline
\end{tabular}

a Bolded values indicate significant dissimilarity $(p<0.05)$.

Stage 1 and Stage 2 (before and after the release) and between Stage 2 and Stage 4 (before and after the release was shut off) were statistically significant $(p<0.05$, Table 2$)$.

Figs. 3-5 and Figs. S3-S8 showed that various aerobic functional genotypes were detected during Stage 2, even though highly reducing conditions prevailed (Table 1 ). Our previous study reported that atmospheric oxygen ( 21\% v:v) penetrated the unsaturated zone (only $45 \mathrm{~cm}$ deep) and reached the water table of this model aquifer system (Ma et al., 2012). In this study, sand samples were collected at 5-30 cm below water table, thus it was most likely that the top part of the sand core was aerobic or hypoxic, which facilitated the survival of some aerobic microorganisms.

\subsection{Changes in the abundance of biodegradation and biogeochemical cycling genes}

\subsubsection{Biodegradation genes for BTEX and other contaminants}

By creating highly reducing and strong anoxic conditions, ethanol blend releases were likely to enhance the metabolic potential for anaerobic BTEX degradation while inhibit that for aerobic degradation. A variety of aerobic and anaerobic BTEX degradation genes were detected in sand samples, indicating the existence of various BTEX degradation pathways in this model aquifer (Fig. 3). However, the temporal changes in the abundance of aerobic and anaerobic BTEX degradation genes were different. Anaerobic degradation genes ( $b s s G$, bss, and $e b d A B C$ ) at Stage 2 were more abundant than Stage 1. In contrast, most of aerobic degradation genes $(a k b F, c a t B, p c h C F$, and $x y l J)$ were less abundant at Stage 2 than at Stage 1, with tom $A B E$ and $x y l M$ as exceptions (Fig. 3).

One common result of releases of relatively large volumes of ethanol-blended fuel was the rapid depletion of available dissolved oxygen, which inhibited aerobic biodegradation of toxic hydrocarbons such as BTEX (Corseuil et al., 1998). This transition to

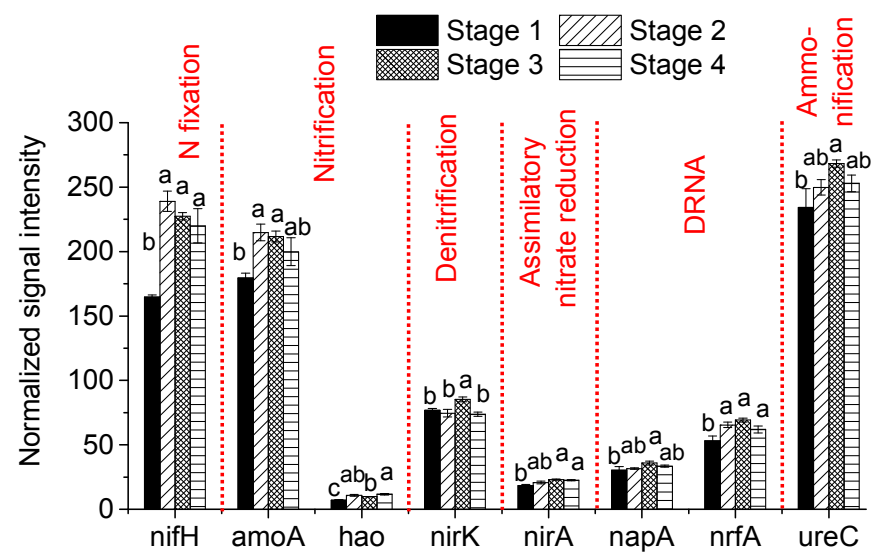

Fig. 4. Normalized signal intensities of nitrogen cycling genes. Letters indicate statistical differences at a $p$ value of $<0.05$ between different treatments by LSD tests. Statistical difference existed between two stages that do not have the same letter. Gene for anaerobic ammonium oxidation ( $h z o$ ) did not have statistical difference among 4 stages, thus was not shown in this figure. DRNA is the abbreviation for dissimilatory nitrate reduction to ammonia.

anaerobic conditions was reflected by our GeoChip data, which showed that the ethanol blend release decreased the abundance of aerobic BTEX degradation genes while increasing the abundance of anaerobic BTEX degradation genes (Fig. 3). A field study similarly reported increased abundance of bssA gene (coding for anaerobic toluene degradation) following an ethanol-blend release (Beller et al., 2008).

Degradation genes for organic contaminants other than BTEX (e.g., aromatic carboxylic acid, alpha hydroxy acid, polycyclic aromatics, heterocyclic aromatics, substituted aromatics, alkane, pesticide and herbicide) were also detected, suggesting this model aquifer was functionally diverse and had degradation potential for a variety of organic contaminants and their potential metabolites (Fig. S3-S5).

\subsubsection{Other carbon cycling genes}

The release significantly $(p<0.05)$ increased the abundance of many $C$ degradation genes (Fig. S6), while did not observe significant $(p>0.05)$ changes in C fixation genes (Fig. S7). Such shifts in carbon cycling potential were conducive to higher heterotrophic activity and $\mathrm{CO}_{2}$ generation in subsurface environments. Two important C cycling gene mcrA (methanogenesis) and fhs

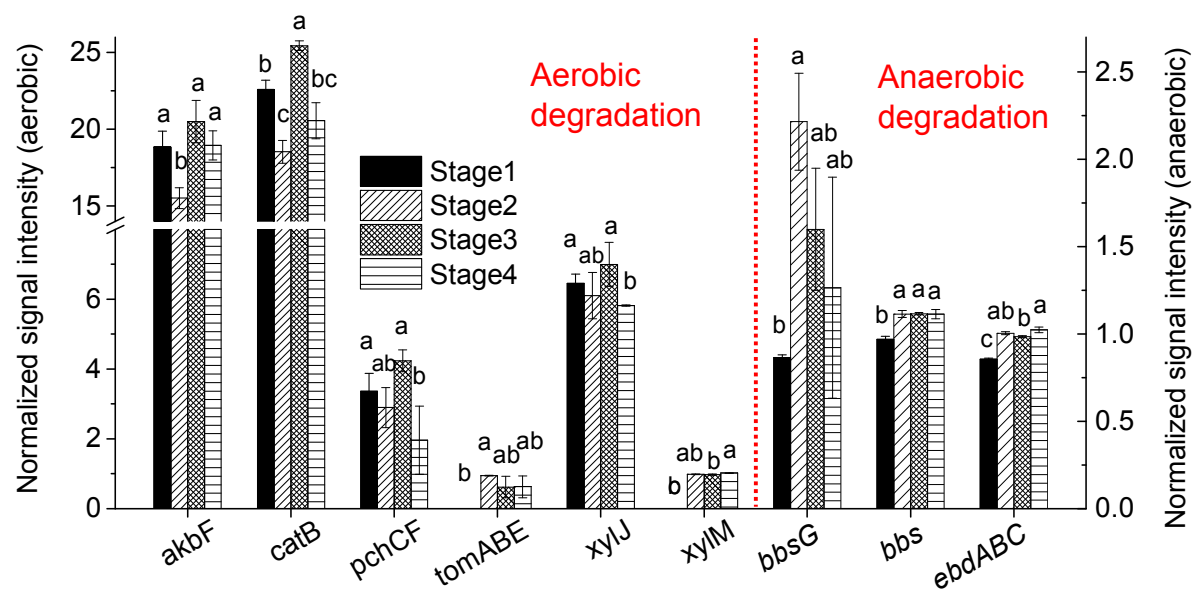

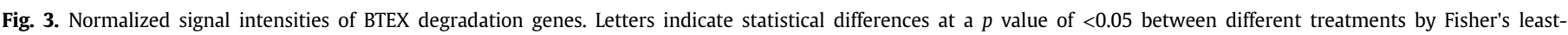
significant-difference (LSD) tests. Statistical difference existed between two stages that do not have the same letter. 


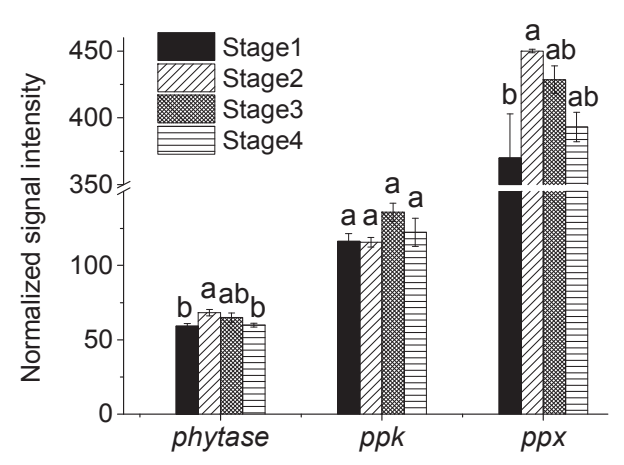

Fig. 5. Normalized signal intensities of functional genes for phosphorus $(\mathrm{P})$ cycling. Letters indicate statistical differences at a $p$ value of $<0.05$ between different treatments by LSD tests. Statistical difference existed between two stages that do not have the same letter.

(acetogenesis) were detected in sand samples. Fig. S8 showed that the release significantly increased the abundance of $m c r A$ and fhs, which was consistent with our previous experiment using qPCR (Ma et al., 2013a, 2015).

\subsubsection{Nitrogen cycling genes}

Ethanol blend releases significantly enhanced microbial metabolic potential for nitrogen $(\mathrm{N})$ fixation and nitrification. As an essential nutrient for all forms of life, $\mathrm{N}$ is a common growthlimiting factor for microorganisms (Atlas and Bartha, 1997). Fig. 4 showed that the abundance of genes for $\mathrm{N}$ fixation (nifH), nitrification ( $a m o A$ and hao), ammonification (ureC) and dissimilatory nitrate reduction to ammonia (DRNA) (napA and $\operatorname{nrfA}$ ) at Stage 2 were significantly higher $(p<0.05)$ than at Stage 1 . In contrast, differences in abundance of denitrification (nirK, norB, and nosZ), anaerobic ammonium oxidation (anammox) ( $h z o$ ), and assimilatory nitrate reduction genes (nir $A$ ) between Stage 2 and Stage 1 were not statistically significant $(p>0.05)$. These results suggested that the ethanol blend release significantly enhanced the metabolic potential for $\mathrm{N}$ fixation and transformation/storage (nitrification), while did not affect $\mathrm{N}$ loss (denitrification and anammox). Thus, we inferred that such adaptive changes in $\mathrm{N}$ cycling potential were likely to increase the abundance of assimilable $N$, potentially enabling microbial growth and biodegradation of the release. Analyses confirmed that sand samples of Stage 2 had higher concentration of nitrate-N than Stage 1 (Table S1). Total N and ammonia-N

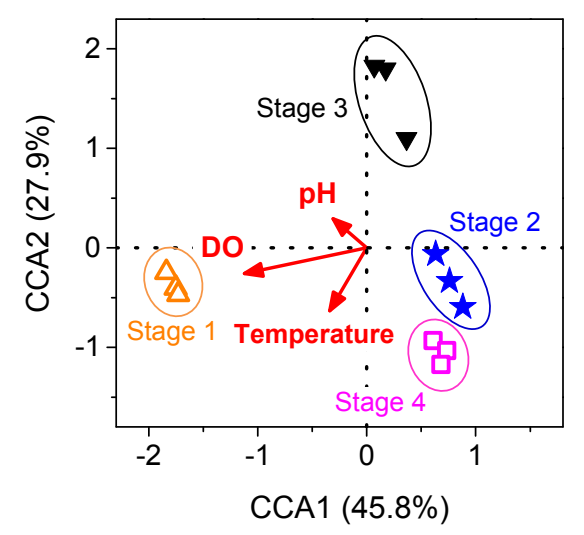

Fig. 6. Canonical correspondence analysis (CCA) of functional gene structure and environmental variables. Environmental variables were chosen based on significance calculated from individual CCA results and variance inflation factor (VIF) calculated during CCA.
Table 3

The relationship of different environmental variables to the overall functional gene structure revealed by Mantel test.

\begin{tabular}{lll}
\hline & r-value & $p$-value \\
\hline pH & 0.350 & $\mathbf{0 . 0 0 8}$ \\
Temperature & 0.199 & 0.063 \\
Dissolved oxygen & 0.628 & $\mathbf{0 . 0 0 1}$ \\
Ethanol & 0.153 & 0.159 \\
Benzene & 0.119 & 0.187 \\
Toluene & 0.213 & 0.061 \\
Methane & 0.153 & 0.146 \\
Acetate & 0.153 & 0.149 \\
Butyrate & 0.153 & 0.151 \\
Butanol & 0.153 & 0.133 \\
\hline
\end{tabular}

a Bolded values indicate significant correlation between environmental variables and overall functional gene structure $(p<0.05)$.

were not measured.

\subsubsection{Phosphorus cycling genes}

The release significantly enhanced the metabolic potential for phosphorus (P) assimilation and utilization. GeoChip contains probes for the enzyme phytase, gene $p p k$ and $p p x$ for P cycling. Phytase breaks down phytate, an indigestible organic form of $\mathrm{P}$ and releases a usable form of inorganic $P$, therefore acting to increase the level of bioavailable P in soil (Menezes-Blackburn et al., 2013). The gene $p p k$ encodes polyphosphate kinase that catalyzes the reversible transfer of the terminal phosphate of ATP to form a longchain polyphosphate (polyP), which is a common $P$ storage form in microbial cells (Rashid et al., 2000). The gene ppx encodes exopolyphosphatase that degrades the long-chain polyP and produces phosphate that is readily usable for microbes (Akiyama et al., 1993). Fig. 5 showed that Stage 2 had significantly $(p<0.05)$ higher abundance of phytase and gene ppx than Stage 1, suggesting that the ethanol blend releases enhanced microbial metabolic potential for $\mathrm{P}$ acquisition and utilization. As an essential nutrient for all forms of life, $\mathrm{P}$ is a common growth-limiting factor for microorganisms (Atlas and Bartha, 1997). Increases in P acquisition and utilization potentials was likely to increase the abundance of biousable $\mathrm{P}$, which was conducive to stimulating microbial growth and biodegradation of ethanol-blended fuel.

\subsubsection{Sulfur cycling genes}

The release significantly enhanced the potential for sulfur $(S)$ cycling, especially sulfate reduction which was a predominant electron-accepting process in many fuel-impacted aquifers (Muyzer and Stams, 2008). Stage 2 had significantly $(p<0.05)$ higher abundance of sulfate reduction genes ( $\operatorname{apr} A, d s r A$, and $d s r B$ ) than Stage 1 (Fig. S9). This result corroborated a field study that used qPCR to show the enrichment of sulfate reduction gene aps following an ethanol blend fuel release (Feris et al., 2008). The releases also significantly $(p<0.05)$ increased the abundance of sulfur oxidation genes (sox, soxB, and soxV, Fig. S9).

\subsection{Dissolved oxygen plays an important role in shaping microbial community structure}

Canonical Correspondence Analysis (CCA) indicated that DO, $\mathrm{pH}$ and groundwater temperature were major environmental factors influencing the microbial community structure (Fig. 6). Mantel test showed that only DO and $\mathrm{pH}$ were significantly $(p<0.05)$ correlated with microbial functional structure, while temperature and pollutant (and byproduct) concentrations (ethanol, benzene, toluene, methane, acetate, butyrate, and butanol) were not (Table 3). Compared to $\mathrm{pH}$, DO had a more pronounced influence on 
functional structure (higher r-value and lower $p$ in Table 3). DO was depleted within 5 days of initiating the release, and rebounded 194 days after the ethanol source was removed (Fig. S2) It is well known that availability of $\mathrm{O}_{2}$ plays a crucial role in shaping aquifer microbial communities and regulating many important biogeochemical processes in subsurface (Griebler and Lueders, 2009). Several studies reported that ethanol-blended releases would deplete dissolved $\mathrm{O}_{2}$ and enriched certain anaerobic functional genotypes such as methanogenesis ( $m c r A$ ) (Ma et al., 2013a), sulfate reduction (aps) (Feris et al., 2008), and BTEX anaerobic degradation (bssA) (Beller et al., 2008; da Silva and Alvarez, 2004). This multivariate statistical analysis corroborated those previous findings.

\subsection{Did microbial functional structure revert to pre-release conditions?}

After the continuous ethanol blended release was shut off (Stage 4 ), the abundance of most functional genes returned back to prerelease (Stage 1) level, but the functional gene structure did not. Figs. 3-5 and S2-S8 showed that the abundance of most functional genes at Stage 4 was not statistically different $(p>0.05)$ from Stage 1 , suggesting that most genes returned to pre-release abundance levels after plume disappeared. However, the NMDS plot showed that the overall functional gene structure at Stage 4 was still quite different from Stage 1 (Fig. 2), which was further confirmed by adonis dissimilarity test ( $p<0.05$, Table 2$)$. On GeoChip, one gene usually contains multiple gene probes covering different coding sequences from different microbial strains (Tu et al., 2014). The signal intensity of one gene is the sum of the signal intensity of all gene probes belonging to that gene, and these gene probes may represent different microbial strains. Our data suggested that although Stage 4 and Stage 1 had same level of gene abundance for most functional genes, their microbial community structures were still quite different. Since Stage 4 was collected only 4 months after the benzene and toluene release was shut off, it is not clear whether the microbial community would eventually return to the prerelease conditions given more time.

\section{Conclusions}

To our best knowledge, this is the first metagenomic study that comprehensively characterized shifts in microbial functional structure throughout the life cycle of a biofuel plume, from initial release through its disappearance. We demonstrated that the ethanol blend release initially enhanced the potential for anaerobic BTEX degradation while decreasing the abundance of most aerobic BTEX degradation genes. The release also enhanced the potential for $\mathrm{N}$ fixation and $\mathrm{P}$ assimilation, which was likely to increase the abundance of bioavailable $\mathrm{N}$ and $\mathrm{P}$ and thus stimulated the broader microbial community, including hydrocarbon degraders. This reflected an adaptive response that was conducive to biodegradation of ethanol-blend releases. We also showed statistically that dissolved $\mathrm{O}_{2}$ was the most influential environmental factor shaping the community structure. After the continuous release was shut off, the abundance of most functional genes shifted towards prerelease conditions, but the final functional structure was significantly different. Longer monitoring periods may be needed to fully understand the microbial response and recovery following the complete attenuation of blended biofuel releases.

\section{Acknowledgments}

This work was funded by the American Petroleum Institute, National Natural Science Foundation of China (No. 21407180), Science Foundation of China University of Petroleum-Beijing (No.
2462014YJRC016), the Office of the Vice President for Research at the University of Oklahoma, and the Collaborative Innovation Center for Regional Environmental Quality.

\section{Appendix A. Supplementary data}

Supplementary data related to this article can be found at http:// dx.doi.org/10.1016/j.envpol.2015.01.005.

\section{References}

Akiyama, M., Crooke, E., Kornberg, A., 1993. An exopolyphosphatase of Escherichia coli. The enzyme and its ppx gene in a polyphosphate operon. J. Biol. Chem. 268, 633-639.

Allison, S.D., Martiny, J.B.H., 2008. Resistance, resilience, and redundancy in microbial communities. Proc. Natl. Acad. Sci. USA 105, 11512-11519.

Atlas, R.M., Bartha, R., 1997. Microbial Ecology: Fundamentals and Applications, fourth ed. Benjamin Cummings, Redwood City, CA.

Beller, H.R., Kane, S.R., Legler, T.C., McKelvie, J.R., Lollar, B.S., Pearson, F., Balser, L., MacKay, D.M., 2008. Comparative assessments of benzene, toluene, and xylene natural attenuation by quantitative polymerase chain reaction analysis of a catabolic gene, signature metabolites, and compound-specific isotope analysis. Environ. Sci. Technol. 42, 6065-6072.

Capiro, N.L., Da Silva, M.L.B., Stafford, B.P., Rixey, W.G., Alvarez, P.J.J., 2008. Microbial community response to a release of neat ethanol onto residual hydrocarbons in a pilot-scale aquifer tank. Environ. Microbiol. 10, 2236-2244.

Chan, Y.K., Van Nostrand, J.D., Zhou, J.Z., Pointing, S.B., Farrell, R.L., 2013. Functional ecology of an Antarctic Dry Valley. Proc. Natl. Acad. Sci. USA 110, 8990-8995.

Corseuil, H.X., Hunt, C.S., Dos Santos, R.C.F., Alvarez, P.J.J., 1998. The influence of the gasoline oxygenate ethanol on aerobic and anaerobic BTX biodegradation. Water Res. 32, 2065-2072.

Corseuil, H.X., Monier, A.L., Fernandes, M., Schneider, M.R., Nunes, C.C., do Rosario, M., Alvarez, P.J.J., 2011. BTEX plume dynamics following an ethanol blend release: geochemical footprint and thermodynamic constraints on natural attenuation. Environ. Sci. Technol. 45, 3422-3429.

da Silva, M.L.B., Alvarez, P.J., 2004. Enhanced anaerobic biodegradation of benzenetoluene-ethylbenzene-xylene-ethanol mixtures in bioaugmented aquifer columns. Appl. Environ. Microbiol. 70, 4720-4726.

da Silva, M.L.B., Corseuil, H.X., 2012. Groundwater microbial analysis to assess enhanced BTEX biodegradation by nitrate injection at a gasohol-contaminated site. Int. Biodeterior. Biodegrad. 67, 21-27.

Elazhari-Ali, A., Singh, A.K., Davenport, R.J., Head, I.M., Werner, D., 2013. Biofuel components change the ecology of bacterial volatile petroleum hydrocarbon degradation in aerobic sandy soil. Environ. Pollut. 173, 125-132.

Feris, K., Mackay, D., de Sieyes, N., Chakraborty, I., Einarson, M., Hristova, K., Scow, K., 2008. Effect of ethanol on microbial community structure and function during natural attenuation of benzene, toluene, and o-xylene in a sulfatereducing aquifer. Environ. Sci. Technol. 42, 2289-2294.

Freitas, J.G., Barker, J.F., 2013. Denatured ethanol release into gasoline residuals, Part 2: fate and transport. J. Contam. Hydrol. 148, 79-91.

Freitas, J.G., Doulatyari, B., Molson, J.W., Barker, J.F., 2011a. Oxygenated gasoline release in the unsaturated zone, Part 2: downgradient transport of ethanol and hydrocarbons. J. Contam. Hydrol. 125, 70-85.

Freitas, J.G. Mocanu, M.T. Zoby, J.L.G., Molson, J.W., Barker, J.F., 2011b. Migration and fate of ethanol-enhanced gasoline in groundwater: a modelling analysis of a field experiment. J. Contam. Hydrol. 119, 25-43.

Griebler, C., Lueders, T., 2009. Microbial biodiversity in groundwater ecosystems. Freshw. Biol. 54, 649-677.

Griebler, C., Malard, F., Lefébure, T., 2014. Current developments in groundwater ecology - from biodiversity to ecosystem function and services. Curr. Opin. Biotechnol. 27, 159-167.

Hazen, T.C., Dubinsky, E.A., DeSantis, T.Z., Andersen, G.L., Piceno, Y.M., Singh, N., Jansson, J.K., Probst, A., Borglin, S.E., Fortney, J.L., Stringfellow, W.T., Bill, M. Conrad, M.E., Tom, L.M., Chavarria, K.L., Alusi, T.R., Lamendella, R., Joyner, D.C., Spier, C., Baelum, J., Auer, M., Zemla, M.L., Chakraborty, R., Sonnenthal, E.L., D'Haeseleer, P., Holman, H.-Y.N., Osman, S., Lu, Z., Van Nostrand, J.D., Deng, Y., Zhou, J., Mason, O.U., 2010. Deep-sea oil plume enriches indigenous oildegrading bacteria. Science 330, 204-208.

Ma, J., Nossa, C.W., Xiu, Z., Rixey, W.G., Alvarez, P.J.J., 2013a. Adaptive microbial population shifts in response to a continuous ethanol blend release increases biodegradation potential. Environ. Pollut. 178, 419-425.

Ma, J., Rixey, W.G., Alvarez, P.J.J., 2013b. Microbial processes influencing the transport, fate and groundwater impacts of fuel ethanol releases. Curr. Opin. Biotechnol. 24, 457-466.

Ma, J., Rixey, W.G., Alvarez, P.J.J., 2015. Increased fermentation activity and persistent methanogenesis in a model aquifer system following source removal of an ethanol blend release. Water Res. 68, 479-486.

Ma, J., Rixey, W.G., DeVaull, G.E., Stafford, B.P., Alvarez, P.J.J., 2012. Methane bioattenuation and implications for explosion risk reduction along the groundwater to soil surface pathway above a plume of dissolved ethanol. Environ. Sci, Technol. 46, 6013-6019. 
160

J. Ma et al. / Environmental Pollution 198 (2015) 154-160

Ma, J., Xiu, Z., Monier, A., Mamonkina, I., Zhang, Y., He, Y., Stafford, B., Rixey, W., Alvarez, P., 2011. Aesthetic groundwater quality impacts from a continuous pilot-scale release of an ethanol blend. Ground Water Monit. Remediat. 31, 47-54.

Mackay, D.M., De Sieyes, N.R., Einarson, M.D., Feris, K.P., Pappas, A.A., Wood, I.A., Jacobson, L., Justice, L.G., Noske, M.N., Scow, K.M., Wilson, J.T., 2006. Impact of ethanol on the natural attenuation of benzene, toluene, and o-xylene in a normally sulfate-reducing aquifer. Environ. Sci. Technol. 40, 6123-6130.

Menezes-Blackburn, D., Jorquera, M.A., Greiner, R., Gianfreda, L., Mora, M.D., 2013. Phytases and phytase-labile organic phosphorus in manures and soils. Crit. Rev. Environ. Sci. Technol. 43, 916-954.

Muyzer, G., Stams, A.J.M., 2008. The ecology and biotechnology of sulphatereducing bacteria. Nat. Rev. Microbiol. 6, 441-454.

Nelson, D.K., Lapara, T.M., Novak, P.J., 2010. Effects of ethanol-based fuel contamination: microbial community changes, production of regulated compounds, and methane generation. Environ. Sci. Technol. 44, 4525-4530.

Powers, S.E., Hunt, C.S., Heermann, S.E., Corseuil, H.X., Rice, D., Alvarez, P.J.J., 2001 a. The transport and fate of ethanol and BTEX in groundwater contaminated by gasohol. Crit. Rev. Environ. Sci. Technol. 31, 79-123.

Powers, S.E., Rice, D., Dooher, B., Alvarez, P.J.J., 2001b. Will ethanol-blended gasoline affect groundwater quality? Using ethanol instead of MTBE as a gasoline oxygenate could be less harmful to the environment. Environ. Sci. Technol. 35 $24 \mathrm{~A}-30 \mathrm{~A}$.

Rashid, M.H., Rumbaugh, K., Passador, L., Davies, D.G., Hamood, A.N., Iglewski, B.H., Kornberg, A., 2000. Polyphosphate kinase is essential for biofilm development, quorum sensing, and virulence of Pseudomonas aeruginosa. Proc. Natl. Acad.
Sci. USA 97, 9636-9641.

Shade, A., Peter, H., Allison, S.D., Baho, D.L., Berga, M., Burgmann, H., Huber, D.H., Langenheder, S., Lennon, J.T., Martiny, J.B.H., Matulich, K.L., Schmidt, T.M., Handelsman, J., 2012. Fundamentals of microbial community resistance and resilience. Front. Microbiol. 3, 417.

Spalding, R.F., Toso, M.A., Exner, M.E., Hattan, G., Higgins, T.M., Sekely, A.C., Jensen, S.D., 2011. Long-term groundwater monitoring results at large, sudden denatured ethanol releases. Ground Water Monit. Remediat. 31, 69-81.

Tu, Q., Yu, H., He, Z., Deng, Y., Wu, L., Van Nostrand, J.D., Zhou, A., Voordeckers, J., Lee, Y.-J., Qin, Y., Hemme, C.L., Shi, Z., Xue, K., Yuan, T., Wang, A., Zhou, J., 2014. GeoChip 4: a functional gene-array-based high-throughput environmental technology for microbial community analysis. Mol. Ecol. Resour. 14 (5), 914-928.

Wang, F.P., Zhou, H.Y., Meng, J., Peng, X.T., Jiang, L.J., Sun, P., Zhang, C.L., Van Nostrand, J.D., Deng, Y., He, Z.L., Wu, L.Y., Zhou, J.H., Xiao, X., 2009. GeoChipbased analysis of metabolic diversity of microbial communities at the Juan de Fuca Ridge hydrothermal vent. Proc. Natl. Acad. Sci. USA 106, 4840-4845.

Zhou, J., Deng, Y., Zhang, P., Xue, K., Liang, Y., Van Nostrand, J.D., Yang, Y., He, Z., Wu, L., Stahl, D.A., Hazen, T.C., Tiedje, J.M., Arkin, A.P., 2014. Stochasticity, succession, and environmental perturbations in a fluidic ecosystem. Proc. Natl. Acad. Sci. 111 (9), E836-E845.

Zhou, J., Xue, K., Xie, J., Deng, Y., Wu, L., Cheng, X., Fei, S., Deng, S., He, Z., Van Nostrand, J.D., Luo, Y., 2012. Microbial mediation of carbon-cycle feedbacks to climate warming. Nat. Clim. Change 2, 106-110. 